E3S Web of Conferences 1, 32005 (2013)

DOI: $10.1051 / \mathrm{e} 3 \operatorname{sconf} / 20130132005$

(C) Owned by the authors, published by EDP Sciences, 2013

\title{
Trace elements concentrations in aquatic biota from the Iron Gates wetlands in Romania
}

\author{
M. L. Matache $^{1}$, A. Tudorache ${ }^{2}$, L. Rozylowicz ${ }^{1}$ and E. Neagu ${ }^{3}$ \\ ${ }^{1}$ Centre for Environmental Research and Impact Studies, University of Bucharest, Bucharest, 010041, ROMANIA \\ 2 Department of Geospeleology and Paleontology,"Emil Racovita" Institute of Speleology of the Romanian Academy, \\ Bucharest, ROMANIA \\ ${ }^{3}$ Research and Development National Institute for Nonferrous and Rare Metals, Bucharest, ROMANIA
}

\begin{abstract}
Concentration of four heavy metals was studied in living organisms from the wetlands ecosystems within the Iron Gates Natural Park in Romania. Samples included aquatic plants (Ceratophyllum ssp., Potamogeton pectinatus, Potamogeton natans), molluscs (Sinanodonta woodiana, Unio tumidus, Unio pictorum) and fish (Silurus glanis, Sander lucioperca, Aspius aspius, Cyprinus carpio, Carassius gibelio). Metals organotropism in fish samples (gills, liver, muscle, eggs) has been studied (Kojadinovici et al., 2007; Foata et. Al, 2009; Dutton and Fisher, 2011; David et al., 2012). Metal contamination of the wetland ecosystems in the Iron Gates Natural Park has been documented in the past for sediments (Matache et. al, 2002) and soils (Matache et al., 2003). This is a consequence of the mining and quarrying activities performed in the Moldova Noua region between 1960's and 2000's. Zinc is the main metal contaminant in all categories of collected samples. For fish muscle tissue (part of the fish mainly consumed by the local inhabitants), comparison with EU standards has been performed. Issues related to human health appear especially for cadmium (EC, 2006). Potamogeton pectinatus is the least accumulating plant species, whilst Potamogeton natans and Ceratophyllum ssp. had shown similar accumulation capacities of the trace elements.
\end{abstract}

Key words: Heavy metals, wetlands, fish, plants, molluscs

\section{Acknowledgements}

This work was supported by the European Commission, Environment Directorate through the project LIFE10 NAT/RO/740 - "Improving the conservation status for the priority species and habitats in the Iron Gates wetlands".

Dr. Marius Matache was supported by the strategic grant POSDRU/89/1.5/S/58852, Project „Postdoctoral programme for training scientific researchers" cofinanced by the European Social Found within the Sectorial Operational Program Human Resources Development $2007-2013$.

\section{References}

Dutton J, Fisher NS. Bioaccumulation of As, Cd, Cr, $\mathrm{Hg}(\mathrm{II})$, and $\mathrm{MeHg}$ in killifish (Fundulus heteroclitus) from amphipod and worm prey. Sci Total Environ 2011; 409: 3438-47.

Foata J, Quilichini Y, Torres J, Pereira E, Spella MM, Mattei J, et al. Comparison of arsenic and antimony contents in tissues and organs of brown trout caught from the river Presa polluted by ancient mining practices and from the river Bravona in Corsica (France): a survey study. Arch Environ Contam Toxicol 2009; 57: 581-9.

Kojadinovic J, Potier M, Le Corre M, Cosson RP, Bustamante P. Bioaccumulation of trace elements in pelagic fish from the Western Indian Ocean. Environ Pollut 2007; 146: 548-66.

David, IG, Matache ML, Tudorache, A, Chisamera, G, Rozylowicz, L, Radu, GL, Food chain biomagnification of heavy metals in samples from the Lower Prut Floodplain Natural Park. Environ Eng Manag $J$ 2012; 11: 69-74

Commission Regulation (EC) No 1881/2006 of 19 December 2006 setting maximum levels for certain contaminants in foodstuffs http://eur-lex.europa.eu/ LexUriServ/LexUriServ.do?uri=CONSLEG:2006R1 881:20100701:EN:PDF

Matache, M, Patroescu, C, Patroescu-Klotz, IV, Evoluţia concentraţiei metalelor grele în sedimente acvifere 
E3S Web of Conferences

dunărene pe tronsonul Baziaş - Porţile de Fier I (1996-1999), Rev Chim 2002; 53: 623-626

Matache, M, Rozylowicz, L, Ropotă, M, Pătroescu, C,
Heavy Metals Contamination Of Soils Surrounding Waste Deposits In Romania. J Phys IV 2003; 107: 851-854. 